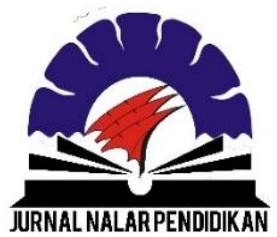

JURNAL NALAR PENDIDIKAN

ISSN [E]: 2477-0515 ISSN [P]: 2339-0794

DOI: 10.26858/jnp.v9i1.20633

Online: https://ojs.unm.ac.id/nalar

\title{
ANALISIS PENGARUH MASA KERJA DAN SERTIFIKASI TERHADAP KOMPETENSI DAN KINERJA GURU PRODUKTIF SMK NEGERI DI KOTA KENDARI
}

\author{
Celia Tri Pristya Devitha1 ${ }^{1}$, Fiskia Rera Baharuddin², ${ }^{2}$ Purnamawati $^{3}$ \\ 1,2,3, Pendidikan Teknologi Kejuruan, Program Pascasarjana, Universitas Negeri Makassar \\ celiadevitha91@gmail.com ${ }^{1}$
}

\begin{abstract}
Abstrak
Penelitian ini bertujuan untuk mendeskripsikan pengaruh langsung dan tidak langsung masa kerja dan sertifikasi terhadap kompetensi dan kinerja guru produktif pada SMK Negeri di Kota Kendari. Penelitian menggunakan metode kuantitatif dengan analisis statistik serta analisis jalur untuk menjawab hipotesis. Populasi dalam penelitian ini berjumlah 208 orang dan sampel penelitian berjumlah 123 orang guru produktif yang ditentukan menggunakan teknik purposive sampling dengan kriteria yang telah ditentukan. Hasil penelitian menunjukkan: 1) tidak terdapat pengaruh signifikan masa kerja terhadap kompetensi guru (Sig. 0,476>0,05); 2) tidak terdapat pengaruh signifikan sertifikasi terhadap kompetensi guru (Sig. 0,264>0,05); 3) tidak terdapat pengaruh signifikan masa kerja terhadap kinerja guru (Sig. 2,40>0,05); 4) terdapat pengaruh signifikan sertifikasi terhadap kinerja guru (Sig. 0,001<0,05); 5) terdapat pengaruh signifikan kompetensi terhadap kinerja guru $(\operatorname{Sig} .0,000<0,05) ; 6$ ) tidak terdapat pengaruh signifikan masa kerja terhadap kinerja guru melalui kompetensi sebagai variabel intervening $(\beta: 0,137)$; dan 7$)$ tidak terdapat pengaruh signifikan sertifikasi terhadap kinerja guru melalui kompetensi sebagai variabel intervening $(\beta: 0,117)$. Rekomendasi yang dapat diberikan kepada guru produktif pada SMK Negeri di Kota Kendari agar dapat terus meningkatkan kompetensi khususnya dalam pemanfaatan media pembelajaran, serta dapat terus memperbaharui ilmu pengetahuan dan keterampilan sesuai perkembangan teknologi.
\end{abstract}

Kata kunci: Masa Kerja, Sertifikasi, Kompetensi, Kinerja, Guru Produktif

\section{ANALYSIS OF THE EFFECT OF TENURE AND CERTIFICATION ON THE COMPETENCY AND PERFORMANCE OF PRODUCTIVE TEACHERS AT STATE VOCATIONAL HIGH SCHOOL IN KENDARI CITY}

\begin{abstract}
This study aims to describe the direct and indirect effects of tenure and certification on the competence and performance of productive teachers at State Vocational High Schools in Kendari City. The research sample consisted of 123 productive teachers who were determined using purposive sampling technique with certain criteria. This study uses quantitative methods with statistical analysis and path analysis to answer the hypothesis. The results showed: 1) there was no significant effect of tenure on teacher competence (Sig. 0.476>0.05); 2) there was no significant effect of certification on teacher competence (Sig. 0.264>0.05); 3) there was no significant effect of tenure on teacher performance (Sig. 2.40>0.05); 4) there was a significant effect of certification on teacher performance (Sig. $0.001<0.05$ ); 5) there was a significant effect of competence on teacher performance (Sig. $0.000<0.05$ ); 6) there was no significant effect of tenure on teacher performance through competence as an intervening variable ( $\beta$ : 0.137); and 7) there was no significant effect of certification on teacher performance through competence as an intervening variable ( $\beta$ : 0.117). Recommendations that can be given to productive teachers at State Vocational High Schools in Kendari City so that they can continue to improve competence, especially in the use of learning media, and can continue to update knowledge and skills according to technological updates.
\end{abstract}




\section{Keywords: Tenure, Certification, Competence, Performance, Productive Teacher}

\section{PENDAHULUAN}

Peningkatan kualitas sumber daya manusia (SDM) dengan berfokus pada unit pendidikan kejuruan melalui Sekolah Menengah Kejuruan (SMK) adalah upaya program pemerintah yang tercantum melalui Instruksi Presiden Nomor 9 Tahun 2016 mengenai Revitalisasi SMK. SMK berperan penting dan strategis dalam memenuhi kebutuhan dunia kerja (DU/DI) melalui pendidikan kejuruan yang menghasilkan SDM terampil dan ahli pada kompetensi keahlian tertentu. Salah satu faktor untuk mendukung terciptanya kualitas pendidikan merupakan peran guru sebagai tenaga pendidik profesional, dimana berkewajiban tidak hanya mengajar atau sekedar mentransfer ilmu pengetahuan, teknologi dan keterampilan, melainkan dapat memberi pengetahuan dan keterampilan melalui pengalaman dalam kehidupan [1].

Djojonegoro dalam referensi [2] mengutip teori Prosser sebagai prinsip-prinsip pendidikan kejuruan, dimana terdapat poin yang mengatakan bahwa "Pendidikan vokasi dapat efektif bila diajarkan oleh guru dan pakar yang mempunyai pengalaman yang mampu mengimplementasikan keterampilan serta pengetahuan terkait operasi dan proses kerja”. Sebagai komponen pendidikan tentu memiliki peran penting, guru produktif secara ideal diharapkan telah menguasai bidang keahlian yang diampunya dengan kompetensi dan kinerja yang optimal. Dalam lampiran V Permendikbud Nomor 34 Tahun 2018 diuraikan kompetensi guru secara umum terdiri atas 4 (empat) kompetensi yang terdiri dari kompetensi pedagogik, sosial, profesional, dan kepribadian [3]. Kompetensi guru dinilai melalui Uji Kompetensi Guru (UKG). UKG merupakan ujian tingkat penguasaan kemampuan profesional dan mengajar melalui aspek kognitif, sebagai acuan penentuan bagian dari pelaksanaan pengembangan keprofesian berkelanjutan serta evaluasi kinerja guru. [4].

Mulyani dalam referensi [5] mengemukakan bahwa adanya pengaruh yang positif dan substansial pada kinerja guru dalam mutu kegiatan belajar SMK sekabupaten Purwakarta dengan persentase pengaruh sebesar 46,7\%. Hasil penelitian ini memberi informasi bahwa semakin baik kinerja guru, tentunya dapat diikuti dengan semakin tinggi pula mutu pembelajaran. Hal tersebut mampu dijelaskan bahwa guru yang mempunyai rata-rata kinerja baik akan memperoleh mutu atau kualitas belajar dan kualitas yang optimal pada peserta didik. Berdasarkan hasil penelitian tersebut, idealnya guru harus memiliki kinerja yang optimal dan berkualitas sehingga dapat memberi kontribusi yang positif dan signifikan pada peningkatan mutu pembelajaran serta meningkatkan prestasi belajar peserta didik.

Berbagai usaha terus diupayakan Pemerintah dalam peningkatan kualitas guru sebagai pendidik serta siswa sebagai peserta didik. Pemerintah juga telah mengalokasikan APBN sebesar $20 \%$ pada bidang Pendidikan termasuk di dalamnya untuk meningkatkan kualitas dan kinerja guru melalui tunjangan sertifikasi. Meski demikian kompetensi guru yang dinilai melalui Uji Kompetensi Guru (UKG) secara nasional menunjukkan rata-rata nilai guru SMK masih belum mencapai standar kelulusan UKG, salah satunya di Kota Kendari. Berdasarkan hasil UKG dalam referensi [6] nilai UKG SMK di Kota Kendari hanya mencapai nilai rata-rata 57,07 dengan nilai pada aspek pedagogik hanya mencapai angka 51,42, sementara nilai UKG pada aspek profesional mencapai angka 55,87. Pencapaian nilai ini menunjukkan bahwa secara umum dapat dilihat kompetensi guru SMK di Kota Kendari masih sangat rendah baik itu kompetensi pedagogik maupun kompetensi profesional, nilainya pun di bawah standar nilai kelulusan UKG yakni 75 . Kondisi ini bisa dikatakan cukup memprihatinkan, mengingat betapa besar peran guru sebagai agen pembelajar untuk membantu meningkatkan kualitas SDM.

Terdapat sejumlah pengaruh antara faktor kinerja guru diantaranya masa kerja, sertifikasi, dan kompetensi guru. Wardoyo \& Supriyoko dalam referensi [7] menjelaskan "masa kerja adalah satu rentang waktu yang dijalankan seseorang dalam profesi keguruan sesuai bidangnya sehingga ia memperoleh pengalaman kerja dalam waktu tersebut. Masa kerja guru dapat dihitung berdasarkan Surat Keputusan pengangkatan sebagai guru baik dari Pemerintah, Pemerintah Daerah, maupun Satuan Pendidikan tertentu sampai saat ini. Hasil penelitian Nasution dan Darmayanti dalam referensi [8] menyebutkan masa kerja memberi pengaruh terhadap kinerja guru. Dalam penelitian tersebut ditemukan guru dengan masa kerja 4 hingga 10 tahun mempunyai kinerja yang lebih optimal dibandingkan guru pada masa kerja lebih dari 10 tahun. Hal ini mendukung pernyataan bahwa 
guru yang mempunyai waktu masa kerja lebih lama dianggap memiliki pengetahuan dan pemahaman yang lebih karena pengalaman bekerjanya. Meski demikian, hasil penelitian tersebut mengungkapkan bahwa kinerja guru masa waktu kerja di atas 10 tahun masa kerja justru lebih rendah dibandingkan guru dengan masa kerja 4-10 tahun.

Faktor lain yang dapat menunjang kompetensi dan kinerja guru adalah sertifikasi. Sertifikasi merupakan pengakuan profesionalitas dan kompetensi guru dalam menjalankan tugas serta profesinya melalui pemberian sertifikat pendidik. Sertifikasi menjadi simbol atas profesionalitas guru sehingga guru yang telah bersertifikasi dianggap memiliki kompetensi yang optimal. Kata sertifikasi merupakan serapan dari kata berbahasa Inggris yakni certification yang berarti secara resmi memangku jabatan secara profesional dengan gelar diploma atau diakui secara resmi [9]. UU No 14 Tahun 2005 menyebutkan "sertifikasi merupakan proses penerimaan sertifikat untuk guru dan dosen sabagai pendidik. Selanjutnya sertifikat pendidik merupakan salah satu bukti formal sebagai pengakuan tenaga profesional yang diterima oleh guru dan dosen atas pengakuan yang diberikan." Hasil penelitian Murwati dalam referensi [10] menyebutkan sertifikasi profesi guru berpengaruh bagi kinerja guru SMK Negeri se-Surakarta, dalam artian bahwa guru yang telah tersertifikasi mempunyai kualitas kinerja yang lebih baik. Sementara itu, menurut hasil penelitian Meliana, Hasyim, \& Yusnica dalam referensi [11] ditemukan suatu pengaruh antara sertifikasi guru dengan kompetensi pedagogik guru dalam mengajar di SMA Negeri 1 Bangunrejo Kecamatan Bangunrejo Kabupaten Lampung Tengah. Meski demikian, belum sesuai pengaruh terhadap tujuan pada sertifikasi guru. Data ini disebabkan karena ketidakoptimalan guru dalam melaksanakan pembelajaran dengan tepat terhadap penetapan aturan. Faktor-faktor yang memberi pengaruh terhadap kompetensi dan kinerja guru inilah yang menjadi landasan penelitian untuk menguji dan menganalisis faktor apakah yang paling berpengaruh dengan kompetensi pada kinerja guru, sehingga dapat diperoleh informasi untuk meningkatkan kompetensi dan kinerja guru, khususnya guru produktif pada SMK di Kota Kendari.

\section{METODE PENELITIAN}

Penelitian dilakukan menggunakan pendekatan kuantitatif, selanjutnya data dipaparkan secara statistik deskriptif dan uji hipotesis menggunakan analisis jalur (path analysis) melalui aplikasi SPSS. Penelitian dilaksanakan pada lima (5) SMK Negeri di Kota Kendari yakni SMK Negeri 1, SMK Negeri 2, SMK Negeri 3, dan SMK Negeri 4, serta SMK Negeri 5 Kendari. Penelitian ini menggunakan data sekunder yang ditemukan dari SMK lokasi penelitian dan Lembaga Penjaminan Mutu Pendidikan (LPMP) Provinsi Sulawesi Tenggara. Selanjutnya, populasi dalam penelitian ini dari seluruh guru produktif pada SMK Negeri di Kota Kendari sejumlah 208 orang, sementara penentuan sampel ditentukan melalui teknik purposive sampling dengan menentukan sampel berdasarkan kriteria tertentu yakni merupakan guru produktif, berstatus Pegawai Negeri Sipil (PNS), dan telah mengikuti Uji Kompetensi Guru (UKG), serta telah memperoleh penilaian kinerja guru oleh tim PKG ataupun pengawas. Berikut tabel jumlah responden dalam penelitian ini:

Tabel 1. Jumlah Sampel Penelitian

\begin{tabular}{llc}
\hline No. & Nama Sekolah & Jumlah Sampel \\
\hline 1 & SMK N 1 Kendari & 27 \\
2 & SMK N 2 Kendari & 47 \\
3 & SMK N 3 Kendari & 23 \\
4 & SMK N 4 Kendari & 15 \\
5 & SMK N 5 Kendari & 11 \\
\hline & Total
\end{tabular}

\section{HASIL DAN PEMBAHASAN}

\section{Hasil}

Deskripsi data responden dalam bagian ini hanya berupa gambaran informasi data terkait ratarata nilai kompetensi dan kinerja guru produktif di SMK Negeri pada Kota Kendari berdasarkan satuan pendidikan, masa kerja, dan sertifikasi. Sementara, pembahasan terhadap pengaruh masa kerja dan sertifikasi bagi kompetensi dan kinerja guru dibahas dalam hasil uji hipotesis.

\section{Kompetensi Guru Produktif SMK Negeri di Kota Kendari}

Nilai kompetensi ini merupakan nilai total dari UKG terhadap kompetensi pedagogik dan kompetensi profesional. Berikut adalah tabel ratarata nilai UKG Guru produktif SMK Negeri di Kota Kendari berdasarkan masa kerja:

Tabel 2. Rerata Kompetensi Berdasarkan Masa Kerja

\begin{tabular}{ccccc}
$\begin{array}{c}\text { Kategori Masa } \\
\text { Kerja }\end{array}$ & Mean & N & Min & Max \\
\hline
\end{tabular}




\begin{tabular}{lcccc}
\hline 10-13 Tahun & 61 & 35 & 35 & 81 \\
14-17 Tahun & 59 & 27 & 40 & 75 \\
18-21 Tahun & 62 & 9 & 50 & 75 \\
22-25 Tahun & 71 & 9 & 55 & 81 \\
26-29 Tahun & 63 & 30 & 43 & 81 \\
30-33 Tahun & 61 & 12 & 36 & 75 \\
34-37 Tahun & 0 & 0 & 0 & 0 \\
38-41 Tahun & 55 & 1 & 55 & 55 \\
\hline
\end{tabular}

Tabel 2 menunjukan jumlah guru produktif paling banyak dengan masa kerja 10 hingga 13 Tahun yakni 35 orang, dan paling sedikit berjumlah 1 orang dengan masa kerja 39 Tahun. Tidak terdapat guru produktif dengan masa kerja antara 34 hingga 37 tahun. Selanjutnya, guru produktif dengan masa kerja antara 22 hingga 25 Tahun sebanyak 9 orang memperoleh rata-rata tertinggi dengan nilai 71 , sementara nilai terendah yakni 55 diperoleh oleh guru dengan masa kerja 38 hingga 41 Tahun dengan jumlah 1 orang. Adapun kompetensi guru produktif pada SMK Negeri di Kota Kendari dapat dilihat pada tabel berikut ini:

Tabel 3. Rata-rata Kompetensi Guru Produktif di SMK Negeri pada Kota Kendari Berdasarkan Sertifikasi

\begin{tabular}{ccccc}
\hline Sertifikasi & Mean & N & Min & Max \\
\hline Belum Sertifikasi & 58 & 19 & 40 & 75 \\
Sudah Sertifikasi & 62 & 104 & 35 & 81 \\
\hline
\end{tabular}

Tabel 3 memberi informasi guru produktif pada SMK Negeri Kota Kendari yang telah tersertifikasi berjumlah 104 orang dengan rata-rata nilai kompetensi 62, nilai terendah 35 dan nilai tertinggi 81. Sementara, guru produktif yang belum tersertifikasi berjumlah 19 orang dengan rata-rata nilai kompetensi 58, adapun nilai terendah 40 dan nilai tertinggi 75 . Guru produktif yang telah tersertifikasi memperoleh nilai yang lebih tinggi daripada guru produktif yang belum tersertifikasi.

\section{Kinerja Guru Produktif SMK Negeri pada Kota Kendari}

Kinerja guru produktif di SMK Negeri Kota Kendari diukur berdasarkan nilai akhir dari PKG yang dilakukan oleh masing-masing sekolah, baik itu oleh Tim Penilai Kinerja Guru (Tim PKG), Kepala Sekolah, dan Pengawas. Berikut adalah tabel rerata kinerja guru produktif pada SMK Negeri di kota Kendari berdasarkan masa kerja:

Tabel 4. Rerata Kinerja Guru Produktif SMK Negeri di Kota Kendari Berdasarkan Masa Kerja

\begin{tabular}{ccccc}
\hline $\begin{array}{c}\text { Kategori } \\
\text { Masa Kerja }\end{array}$ & Mean & N & Min & Max \\
\hline 10-13 Tahun & 84 & 35 & 79 & 89 \\
14-17 Tahun & 84 & 27 & 77 & 89 \\
18-21 Tahun & 84 & 9 & 79 & 91 \\
\hline
\end{tabular}

$\begin{array}{lcccc}\text { 22-25 Tahun } & 84 & 9 & 82 & 86 \\ \text { 26-29 Tahun } & 85 & 30 & 77 & 93 \\ \text { 30-33 Tahun } & 86 & 12 & 80 & 93 \\ \text { 38-41 Tahun } & 88 & 1 & 88 & 88\end{array}$

Tabel 4 menunjukan nilai kinerja tertinggi diperoleh oleh guru produktif pada masa kerja antara 38-41 tahun dengan jumlah 1 orang. Selanjutnya, guru senior dengan masa kerja 30 hingga 33 tahun memperoleh nilai kinerja 86, dan guru senior dengan masa kerja 26 hingga 29 tahun memperoleh nilai kinerja 85. Guru produktif dengan masa kerja 10 hingga 25 tahun memiliki rata-rata nilai kinerja terendah yakni 84 tahun. Berbeda dengan kompetensi, kinerja guru produktif senior dengan masa kerja 30 hingga 41 tahun justru lebih tinggi. Selanjutnya rata-rara kinerja guru berdasarkan sertifikasi tercantum melalui tabel berikut:

Tabel 5. Rerata Kinerja Guru Produktif SMK Negeri di Kota Kendari Berdasarkan Sertifikasi

\begin{tabular}{ccccc}
\hline Sertifikasi & Mean & N & Min & Max \\
\hline Belum Sertifikasi & 81 & 19 & 78 & 86 \\
Sudah Sertifikasi & 85 & 104 & 77 & 93
\end{tabular}

Tabel 5 menunjukkan rata-rata nilai kinerja guru produktif yang belum tersertifikasi adalah 81 . Nilai ini lebih rendah daripada rata-rata kinerja guru produktif yang telah tersertifikasi yakni 85 . Meskipun selisih nilai ini terpaut 4 angka, namun dapat disimpulkan bahwa guru produktif yang menerima setifikasi memperoleh kualitas pendidik yang lebih baik daripada guru produktif belum tersertifikasi.

\section{Uji Asumsi Klasik}

Uji asumsi klasik diterapkan untuk uji prasyarat analisis regresi linear berganda.

\section{Uji Normalitas}

Pengujian normalitas penelitian ini diuji dengan Uji Kolmogorov-Smirnov. Pengujian normalitas tercantum pada tabel dibawah ini:

Tabel 6. Hasil Uji Normalitas Kolmogorov-Smirnov

\begin{tabular}{lccc}
\hline \multicolumn{1}{c}{ Variabel } & $\boldsymbol{\alpha}$ & Sig. & Ket \\
\hline Masa Kerja (X1) & 0,05 & 0,690 & Normal \\
\hline Sertifikasi (X2) & 0,05 & 0,200 & Normal \\
\hline Kompetensi (Y) & 0,05 & 0,367 & Normal \\
\hline Kinerja (Z) & 0,05 & 0,085 & Normal \\
\hline Hasil uji & Kolmogorov-Smirnov & di tabel 6 \\
memperoleh nilai & Asympotic & Significance \\
(Asymp.Sig 2-tailed) & untuk semua variabel lebih \\
besar selain 0,05. Dengan demikian bisa \\
disimpulkan bahwa seluruh data dalam penelitian
\end{tabular}

\section{Uji Linearitas}

Uji linearitas bertujuan mengetahui keberadaan hubungan yang signifikan antara dua variabel. Uji linieritas dilakukan hanya untuk variabel masa kerja dan kompetensi dengan kinerja guru. Berikut adalah 
hasil uji linieritas:

Tabel 7. Hasil Uji Linieritas

\begin{tabular}{lccc}
\hline \multicolumn{1}{c}{ Variabel } & $\boldsymbol{\alpha}$ & Sig. & Ket \\
\hline Masa Kerja*Kinerja & 0,05 & 0,536 & Linear \\
\hline Masa Kerja*Kompetensi & 0,05 & 0,375 & Linear \\
\hline Kompetensi*Kinerja & 0,05 & 0,392 & Linear
\end{tabular}

Tabel 7 menunjukkan nilai Sig. untuk hubungan antara variabel masa kerja terhadap kinerja adalah $0,536>0,05$. Atas hasil analisis ini bisa disimpulkan ada hubungan yang linear diantara variabel masa kerja terhadap variabel kinerja. Selanjutnya, untuk variabel kompetensi dengan variabel kinerja ditemukan nilai nilai Sig. sebesar 0,392 > 0,05 yang bermakna terdapat hubungan yang linier antara variabel kompetensi dengan variabel kinerja.

\section{Uji Multikolinearitas}

Uji multikolonieritas memiliki tujuan agar mengetahui terdapatnya hubungan antar variabel bebas (independen) terhadap model regresi. Pengambilan keputusan ada atau tidaknya gejala multikolinearitas berpatokan pada nilai Variance Inflation Factor (VIF) tidak lebih dari 10,00 dan nilai Tolerance tidak kurang dari 0,10 . Berikut hasil analisis uji multikolinearitas:

Tabel 8. Hasil Uji Multikolinearitas

\begin{tabular}{rlcc}
\hline \multirow{2}{*}{ Model } & \multicolumn{2}{c}{ Collinearity Statistics } \\
\cline { 3 - 4 } & & Tolerance & VIF \\
\hline 1 & Masa_Kerja & 0,885 & 1,129 \\
\cline { 2 - 3 } & Sertifikasi & 0,880 & 1,136 \\
\cline { 2 - 3 } \multicolumn{2}{c}{ Kompetensi } & 0,979 & 1,022 \\
\hline \multirow{2}{*}{ a. Dependent Variable: Kinerja_Guru } \\
\hline \multicolumn{2}{c}{ Pada tabel 8 bisa dilihat nilai tolerance terhadap }
\end{tabular}
variabel masa kerja, sertifikasi, dan kompetensi semuanya di atas 0,10 . Selanjutnya, nilai Variance Inflation Factor (VIF) dari semua variabel di bawah 10,00. Berdasarkan hasil analisis dapat disimpulkan data telah memenuhi syarat yakni tidak terjadi gejala multikolinearitas.

\section{Uji Heteroskedastisitas}

Uji heteroskedastisitas bertujuan menguji kesamaan variasi (variance) dalam model regresi. Dalam penelitian ini digunakan Uji Glejser untuk mendeteksi gejala heteroskedastisitas. Berikut hasil uji heteroskedastisitas dengan Uji Glejser:

Tabel 9. Hasil Uji Heteroskedastisitas

\begin{tabular}{|c|c|c|}
\hline Variabel & $\alpha$ & Sig. \\
\hline Masa_Kerja & 0,05 & 0,922 \\
\hline Sertifikasi & 0,05 & 0,254 \\
\hline Kompetensi & 0,05 & 0,208 \\
\hline
\end{tabular}

Hasil analisis pada tabel 9 menunjukkan nilai signifikansi (Sig.) dari seluruh variabel lebih besar dari 0,05 . Oleh karena itu berdasarkan data yang diperoleh, tidak terjadi gejala heteroskedastisitas pada data penelitian.

\section{Uji Hipotesis}

Pengujian hipotesis dilakukan guna menguji apakah hipotesis penelitian diterima atau ditolak dengan menggunakan analisi jalur atau path analysis. Berikut adalah hasil uji analisis model struktural pertama yakni menguji pengaruh variabel masa kerja (X1) dan sertifikasi (X2) terhadap kompetensi guru (Y):

Tabel 10. Hasil Uji Regresi Model Struktural 1

\begin{tabular}{|c|c|c|c|c|c|c|}
\hline & & & Defficients & & & \\
\hline & & Unstandardize & Coefficients & $\begin{array}{l}\text { Standardized } \\
\text { Coefficients }\end{array}$ & & \\
\hline Model & & $B$ & Std. Error & Beta & $t$ & Sig. \\
\hline 1 & (Constant) & 57.106 & 3.012 & & 18.961 & $<, 001$ \\
\hline & MasaKerja & .095 & .133 & .069 & .715 & .476 \\
\hline & Sertifikasi & 3.087 & 2.752 & .107 & 1.122 & .264 \\
\hline
\end{tabular}

Tabel 10 menunjukkan nilai signifikansi (Sig.) dari variabel masa kerja (X1) adalah 0,476>0,05, dan variabel sertifikasi (X2) adalah 0,264 > 0,05. Dengan demikian dapat disimpulkan bahwa Regresi Model Struktural 1 yakni variabel X1 dan X2 tidak berpengaruh terhadap variabel Y. Artinya hipotesis pertama dan kedua dinyatakan ditolak. Dengan kata lain, tidak ditemui pengaruh yang signifikan masa kerja dengan kompetensi guru, dan tidak ditemui pengaruh yang substansial sertifikasi terhadap kompetensi guru produktif pada SMK Negeri di Kota Kendari.

Secara umum, masyarakat berasumsi bahwa guru yang telah bekerja untuk waktu yang lama (masa kerja tinggi) berarti telah memperoleh banyak pengalaman serta penguasaan kompetensi baik itu dalam mengajar maupun pada penyelenggaraan tugas lainnya sebagai sosok pendidik daripada guru yang belum mempunyai banyak pengalaman mengajar (waktu masa kerja rendah). Meski demikian, nilai UKG sendiri menunjukan nilai yang sangat beragam, baik untuk guru junior dengan masa kerja di bawah 20 tahun, hingga guru senior dengan masa kerja di atas 20 tahun.

Hasil wawancara sambil lalu dalam proses penelitian, Kepala SMK Negeri 1 Kendari mengakui bahwa tingkat kompetensi guru-guru produktif SMK Negeri 1 Kendari cenderung menurun khusus pada guru-guru senior yang mendekati masa pensiun. Sementara itu guru-guru senior 
mengungkapkan bahwa mereka menghadapi sejumlah kendala diantaranya kurangnya pengetahuan dalam menggunakan perangkat komputer pada saat ujian daring, soal-soal dalam aspek pedagogik terlalu teoritis sehingga sulit dimengerti, serta adanya kemiripan jawaban yang membuat guru sulit menentukan jawaban yang benar. Kendala tersebut dapat menjadi evaluasi bagi guru sendiri sebagaimana diungkapkan Arfandi, Purnamawati, dan Nurfaedah dalam referensi [12] bahwa guru di Indonesia harus mampu menggunakan teknologi informasi dalam proses pembelajaran khususnya di era revolusi industri 4.0, bukan sekedar menguasai empat aspek kompetensi saja.

Hasil penelitian Muslimin dalam referensi [13] mengungkapkan bahwa UKG melalui standar kompetensi dan sertifikasi guru sangat penting sebab berperan sebagai alat dalam upaya pengembangan standar kompetensi guru agar bisa diketahui kemampuan rata-rata dari guru, peningkatan terhadap beberapa aspek, guru yang memerlukan pembinaan, hingga guru yang sudah memperoleh standar kemampuan minimal. Sertifikasi sendiri adalah sebuah bukti yang menunjukan tingkat profesionalitas guru. Namun, realita yang terjadi guru yang tersertifikasi masih banyak yang tidak mencapai nilai standar minimal UKG yang menunjukkan bahwa tujuan sertifikasi belum tercapai secara optimal.

Pada tabel 10 juga dapat dilihat nilai standardized coefficients Beta untuk variabel masa kerja (X1) sebesar 0,069 kemudian pada variabel sertifikasi (X2) sebesar 0,107. Sehingga dapat diperoleh diagram jalur Regresi Model Strukutral 1 pada gambar berikut:

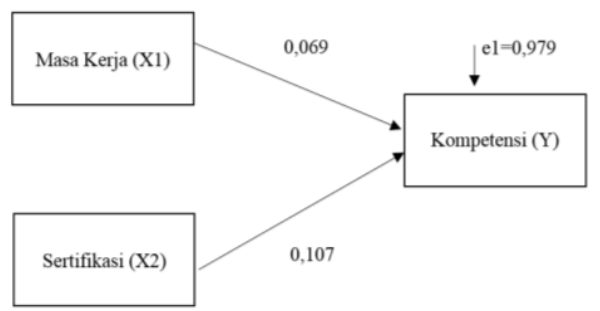

Gambar 3. Diagram Regresi Model Struktural 1

Hasil penelitian juga menunjukkan bahwa sertifikasi tidak berpengaruh terhadap kompetensi guru. Hasil analisis deskriptif telah diuraikan ratarata nilai UKG guru produktif SMK Negeri di Kota Kendari yang telah tersertifikasi adalah 62, adapun nilai terendah sebanyak 35 dan nilai tertinggi sebesar 81. Hal ini menunjukan meskipun sudah tersertifikasi, masih ada guru yang hanya mencapai nilai 35, sementara guru produktif yang belum tersertifikasi mencapai nilai minimum 40 dan maksimum 75 .

Sertifikasi sendiri merupakan sebuah bukti yang menunjukan tingkat profesionalitas guru. Namun, realita yang terjadi guru yang tersertifikasi masih banyak yang tidak mencapai nilai standar minimal UKG yang menunjukkan bahwa tujuan sertifikasi untuk meningkatkan kompetensi guru belum dapat terwujud. Hal ini didukung oleh penelitian Anggranei dalam referensi [14] yang menyatakan bahwa meski sudah bersertifikasi, para guru belum dapat dikatakan sebagai guru yang kompeten dan profesional yang dibuktikan oleh lemahnya pengetahuan guru terhadap peraturan-peraturan sertifikasi. Lebih lanjut dijelaskan Anggranei bahwa guru dalam melaksanakan tugasnya sebagai tenaga pendidik hanya sebatas menggugurkan kewajiban.

Pengujian selanjutnya adalah menguji hipotesis model struktural 2 yakni menguji pengaruh variabel masa kerja (X1), sertifikasi (X2), dan kompetensi $(\mathrm{Y})$ terhadap kinerja guru $(\mathrm{Z})$. Adapun hasil analisis dapat dilihat pada tabel berikut:

Tabel 11. Hasil Uji Regresi Model Struktural 2

\begin{tabular}{|c|c|c|c|c|c|c|}
\hline \multicolumn{7}{|c|}{ Coefficients $^{a}$} \\
\hline \multirow[b]{2}{*}{ Model } & & \multicolumn{2}{|c|}{ Unstandardized Coefficients } & \multirow{2}{*}{$\begin{array}{c}\text { Standardized } \\
\text { Coefficients } \\
\text { Beta }\end{array}$} & \multirow[b]{2}{*}{$t$} & \multirow[b]{2}{*}{ Sig. } \\
\hline & & $B$ & Std. Error & & & \\
\hline \multirow[t]{4}{*}{1} & (Constant) & 71.954 & 1.819 & & 39.548 & $<, 001$ \\
\hline & MasaKerja & .047 & .040 & .095 & 1.180 & .240 \\
\hline & Sertifikasi & 2.944 & .836 & .284 & 3.521 & $<, 001$ \\
\hline & Kompetensi & .149 & .028 & .413 & 5.402 & $<, 001$ \\
\hline
\end{tabular}

Tabel 11 menunjukkan nilai signifikansi (Sig.) pada variabel masa kerja (X1) sebesar 0,240>0,05 dan nilai t hitung $1,180>1,997$. Maka diperoleh kesimpulan bahwa hipotesis ketiga dinyatakan ditolak yakni tidak ditemui pengaruh signifikan antara masa kerja terhadap kinerja guru. Artinya bahwa meskipun masa kerja rendah tidak berarti kinerja guru produktif tersebut rendah, begitu pula sebaliknya. Hasil penelitian Hendra Harish dalam referensi [15] menemukan bahwa lama tidaknya masa kerja guru tidak serta merta dapat berpengaruh secara ideal bagi guru dalam hal menyelesaikan tugas tepat waktu dan menunjukkan hasil kerja yang berkualitas. Di sisi lain, berdasarkan hasil observasi dan wawancara sambil lalu dalam proses penelitian, salah satu guru produktif pada SMK Negeri 5 
Kendari menjelaskan bahwa kinerja guru dengan masa kerja di atas 25 tahun lebih tinggi sebab golongan dan pangkat dalam jabatan juga lebih tinggi. Sementara guru produktif dengan masa kerja kurang dari 25 tahun cenderung memperoleh nilai kinerja yang lebih rendah. Nilai kinerja guru pada SMK Negeri 1 dan SMK Negeri 4 Kendari cukup beragam baik itu bagi guru produktif yang sudah mengajar kurang dari 20 tahun maupun guru produktif lebih dari 20 tahun mengajar. Hal ini memperoleh hasil bahwa meskipun guru produktif telah memperoleh banyak pengalaman selama masa kerjanya, tidak menjamin kinerja guru tersebut menjadi lebih baik. Fenomena ini bisa terjadi ketika masa kerja guru bertambah, maka guru cenderung merasakan kejenuhan dalam melaksanakan tugas yang telah menjadi rutinitasnya, sebaliknya guru yang belum berpengalaman dengan masa kerja rendah membutuhkan waktu dalam melakukan adaptasi tugas serta lingkungan kerja baru sehingga kinerjanya kurang maksimal.

Selanjutnya, variabel sertifikasi (X2) memiliki nilai signifikansi (Sig.) $0,001<0,05$ dan nilai $\mathrm{t}$ hitung 3,521 > 1,997 maka diperoleh kesimpulan bahwa hipotesis keempat dinyatakan diterima. Artinya bahwa terpengaruh signifikan sertifikasi terhadap kinerja guru produktif di SMK Negeri Kota Kendari. Dengan artian, guru produktif yang telah tersertifikasi mendukung guru memiliki kinerja yang baik atau tinggi. Data yang diperoleh dari hasil penelitian ini mendukung beberapa hasil penelitian serupa diantaranya penelitian Ristianey, Harapan, dan Destiniar dalam referensi [16] yang menjelaskan bahwa sertifikasi guru memiliki pengaruh positif pada kinerja guru. Hasil penelitian sebagaimana yang telah diuraikan pada deksripsi rata-rata kinerja guru berdasarkan sertifikasi menunjukkan adanya perbedaan yang nyata dilihat dari kinerja guru yang belum sertifikasi dibandingkan guru yang telah sertifikasi. Guru produktif yang telah sertifikasi memperoleh nilai kinerja yang lebih tinggi dibandingkan guru produktif yang belum sertifikasi. Program sertifikasi baik itu melalui Pendidikan dan Latihan Profesi Guru (PLPG) maupun melalui program Pendidikan dan Profesi Guru (PPG) membekali guru dengan ilmu pengetahuan dan keterampilan dalam mempersiapkan pembelajaran, melaksanakan proses pembelajaran, hingga evaluasi pembelajaran sesuai standar nasional, sehingga guru yang telah sertifikasi cenderung memiliki kelengkapan perangkat pembelajaran yang lebih baik dibandingkan pada guru yang belum sertifikasi. Tentunya ini menjadi faktor pendukung guru yang telah tersertifikasi mempunyai kinerja yang lebih baik daripada guru yang belum menerima sertifikasi.

Hasil peneltiain pada variabel kompetensi (X3) memiliki nilai signifikansi (Sig.) $0,000<0,05$ dan nilai t hitung 5,402>1,997 yang berarti bahwa hipotesis kelima dinyatakan diterima dan disimpulkan terdapat pengaruh siginifikan kompetensi terhadap kompetensi guru produktif SMK Negeri pada Kota Kendari. Data hasil penelitian memperoleh dan mendukung beberapa hasil penelitian lain, diantaranya penelitian Tatan Zaenal dalam referensi [17] yang menemukan bahwa keseluruhan jumlah kompetensi guru sudah memberikan pengaruh signifikan $42.55 \%$ (positif dan signifikan) terhadap kinerja guru, serta penelitian Taufik dan Ridwan dalam referensi [18] yang mengungkapkan pengaruh signifikan terhadap kinerja guru melalui kompetensi. Kompetensi pada dasarnya merujuk dalam kecakapan individu dalam menuntaskan tugas dan tanggungjawab yang diamanahkan kepadanya untuk memperoleh hasil baik [19]. Oleh sebab itu, penguasaan kompetensi bagi guru produktif sangat penting guna menunjang kinerjanya baik melalui proses kegiatan belajar dalam kelas, ataupun melalui pelaksanaan di luar kelas dengan tugas tambahan. Guru produktif sebagai guru kejuruan harus dapat memenuhi salah satu prinsip kejuruan berdasarkan teori Prosser yang menyatakan bahwa guru atau pakar yang sudah berpengalaman dan dapat mengimplementasikan keterampilan bahkan pengetahuan terkait operasi dan proses kerja dapat mendukung terlaksananya pendidikan kejuruan yang efektif.

Guru-guru produktif perlu untuk terus menjadi individu pembelajar baik itu melalui pendidikan dan pelatihan yang relevan, serta terus mengikuti perkembangan teknologi (up-to-date) guna menunjang kompetensinya, yang kemudian dapat pula meningkatkan kinerjanya. Selanjutnya untuk menghitung koefisien jalur pada Regresi Model Struktural 2 tercantum nilai Standardized Coefficients Beta dalam variabel masa kerja (X1) sebesar 0,095, variabel sertifikasi (X2) sebesar 0,284, dan variabel kompetensi (Y) sebesar 0,413. Maka dapat diperoleh diagram jalur Regresi Model Struktural 2 dibawah ini: 


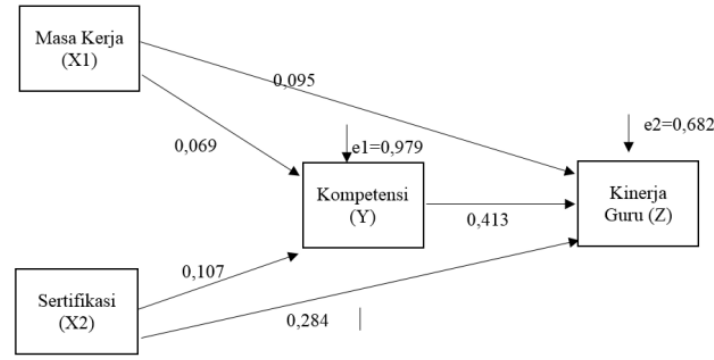

Gambar 4. Diagram Regresi Model Struktural 2

Pengujian hipotesis keenam dan ketujuh dilakukan dengan menghitung pengaruh tidak langsung variabel masa kerja (X1) terhadap kinerja guru (Z) melalui kompetensi (Y), dan pengaruh tidak langsung variabel sertifikasi (X2) terhadap kinerja guru (Z) melalui kompetensi (Y). Untuk menguji hipotesis keenam, nilai pengaruh langsung X1 terhadap Z sebesar 0,095. Selanjutnya pengaruh tidak langsung variabel $\mathrm{X} 1$ terhadap $\mathrm{Z}$ melalui $\mathrm{Y}$ yaitu $0,069 \times 0,413=0,028$. Maka pengaruh total adalah $0,095+0,028=0,123$. Berdasarkan hasil perhitungan tersebut diperoleh nilai pengaruh langsung 0,095 lebih besar dibandingkan dengan nilai pengaruh tidak langsung 0,028. Dengan demikian dapat disimpulkan bahwa hipotesis keenam ditolak, artinya tidak terdapat pengaruh signifikan masa kerja terhadap kinerja guru produktif SMK Negeri di Kota Kendari melalui kompetensi guru. Baik masa kerja maupun sertifikasi tidak berpengaruh terhadap kompetensi, dan pengaruh langsung kedua variabel tersebut bagi kompetensi guru lebih besar dibandingkan pengaruh tidak langsung dari perolehan variabel intervening. Maka hal ini juga menunjukan pengaruh kinerja guru dari variabel lain yang tidak disebutkan di terhadap penelitian ini. Mangkunegara dalam referensi [20] mengungkapkan bahwa terdapat sejumlah faktor yang mendukung kinerja guru yakni faktor internal yang terdiri dari kecerdasan, keterampilan, bakat, kemampuan dan minat, motivasi, kesehatan, kepribadian, serta cita-cita dan tujuan dalam bekerja. Faktor lainnya adalah faktor eksternal yang terdiri mulai dari lingkungan keluarga, lingkungan kerja, komunikasi bersama kepala sekolah, sarana \& prasarana, kegiatan guru dalam kelas dan kegiatan guru pada saat di sekolah.

Kinerja guru produktif dapat ditingkatkan dengan melihat faktor-faktor yang mendukung peningkatan kinerja itu sendiri. Bagi guru produktif di SMK Negeri Kota Kendari, peningkatan kinerja dapat dilakukan melalui program pelatihan yang sesuai dengan kebutuhan guru, misalnya pelatihan pemanfaatan teknologi untuk mendukung proses pembelajaran. Peningkatan kinerja guru produktif di SMK Negeri Kota Kendari juga dapat ditingkatkan melalui peningkatan motivasi kerja, sebab dilihat dari masa kerja baik guru produktif yang senior maupun junior tidak memiliki perbedaan kinerja, penyebabnya bukan hanya ketidakmampuan guru tetapi juga ketidakmauan guru tersebut. Untuk itu, sangat perlu dilakukan peningkatan motivasi guru, mengembalikan tujuan dan misi guru sebagai tenaga profesional yang memiliki peran utama terhadap upaya peningkatan kualitas SDM melalui pendidikan. Melalui hasil penelitian ini, diharapkan guru dapat memiliki dorongan kuat untuk bekerja sesuai dengan standar atau bahkan lebih dari standar kinerja yang telah ditetapkan.

Pengujian hipotesis ketujuh, diketahui pengaruh langsung yang diberikan X2 terhadap Z sebesar 0,284 . Sementara pengaruh tidak langsung variabel $\mathrm{X} 1$ terhadap $\mathrm{Z}$ melalui $\mathrm{Y}$ yaitu $0,284 \times 0,413=$ 0,117 . Maka pengaruh total adalah $0,284+0,117=$ 0,401 . Berdasarkan hasil perhitungan tersebut diperoleh nilai pengaruh langsung 0,284 lebih besar dibandingkan dengan nilai pengaruh tidak langsung 0,117 . Dengan demikian ditemukan bahwa hipotesis ketujuh ditolak, yang berarti tidak terdapat pengaruh signifikan sertifikasi terhadap kinerja guru produktif SMK Negeri di Kota Kendari melalui kompetensi guru. Berbeda dengan masa kerja, sertifikasi secara langsung berpengaruh terhadap kinerja guru produktif SMK Negeri di Kota Kendari, namun tidak berpengaruh signifikan apabila melalui variabel intervening yakni kompetensi. Hal ini disebabkan sertifikasi tidak berpengaruh signifikan terhadap kompetensi guru. Secara teoritis, guru yang sudah memiliki sertifikat pendidik seharusnya menguasai kompetensi yang baik sebab telah mengikuti pendidikan dan pengembangan kompetensi dalam program sertifikasi sehingga dapat meningkatkan kinerja guru tersebut. Namun, dalam penelitian ini teori tersebut tidak terjadi, hal ini bisa saja disebabkan oleh penilaian kompetensi guru dalam penelitian diukur melalui nilai UKG, dimana rata-rata nilai UKG guru yang telah sertifikasi masih tergolong rendah sehingga tidak dapat mendukung bagi peningkatan kinerja guru secara tidak langsung.

Penelitian Muslimin dalam referensi [13] mengungkapkan bahwa uji kompetensi guru terhadap standar kompetensi serta sertifikasi guru 
sangat penting sebab berperan sebagai alat dalam merumuskan standar kompetensi guru, bisa dilihat rerata kemampuan guru, kemudian aspek mana saja yang mesti ditingkatkan, guru mana yang mesti bimbingan terus menerus, dan guru mana yang sudah mencapai standar kompetensi minimal. Hal ini dapat menjadi evaluasi bagi guru produktif di SMK Negeri pada Kota Kendari khususnya bagi sekolah tersertifikasi untuk selalu menyesuaikan kompetensinya dengan perkembangan teknologi guna mendukung kualitas proses pembelajaran serta meningkatkan kapasitas guru dalam penguasaan kompetensi yang menunjang kinerjanya.

\section{KESIMPULAN}

Berdasarkan hasil penelitian pengaruh masa kerja dan sertifikasi terhadap kompetensi dan kinerja guru produktif pada SMK Negeri di Kota Kendari, maka ditarik suatu kesimpulan mencakup sebagai berikut: 1) Tidak terdapat pengaruh signifikan masa kerja guru terhadap kompetensi guru produktif pada SMK Negeri di Kota Kendari. Nilai UKG sangat beragam baik bagi guru dengan masa kerja lebih dari 20 tahun maupun kurang dari 10 tahun. 2) Tidak terdapat pengaruh signifikan sertifikasi terhadap kompetensi guru produktif pada SMK Negeri di Kota Kendari. Sertifikasi tidak menjamin guru produktif memperoleh kompetensi yang tinggi pula. Hal ini menunjukkan bahwa tujuan sertifikasi sendiri sebagai program untuk meningkatkan kompetensi guru dan bukti terhadap profesionalitas guru belum tercapai secara optimal. 3) tidak terdapat pengaruh signifikan masa kerja guru terhadap kinerja guru produktif pada SMK Negeri di Kota Kendari. Sama halnya dengan kompetensi, nilai kinerja guru produktif pada SMK Negeri di Kota Kendari cenderung beragam baik bagi guru dengan masa kerja di bawah 20 tahun maupun guru yang telah bekerja di atas 20 tahun. 4) Terdapat pengaruh signifikan sertifikasi terhadap kinerja guru produktif pada SMK Negeri di Kota Kendari. Meskipun sertifikasi tidak berpengaruh terhadap kompetensi yang diukur melalui nilai UKG, namun sertifikasi terbukti berpengaruh terhadap kinerja guru yang diukur melalui Penilaian Kinerja Guru (PKG). 5) Terdapat pengaruh signifikan kompetensi terhadap kinerja guru produktif pada SMK Negeri di Kota Kendari. Artinya semakin tinggi kompetensi guru produktif maka semakin tinggi pula kinerjanya. Kompetensi mendukung peningkatan kinerja guru produktif. 6) Tidak terlihat pengaruh signifikan masa kerja pada kinerja guru produktif di SMK Negeri di Kota Kendari melalui kompetensi guru sebagai variabel inetervening. 7) Tidak terdapat pengaruh signifikan sertifikasi terhadap kinerja guru produktif pada SMK Negeri di Kota Kendari melalui kompetensi guru sebagai variabel inetervening.

\section{DAFTAR PUSTAKA}

[1] F. R. Baharuddin and A. M. Palerangi, "Pengaruh Praktik Pengalaman Lapangan Terhadap Kesiapan Menjadi Guru Profesional," Pinisi: Journal of Teacher Professional, 2020.

[2] W. Djojonegoro, Pengembangan Sumber Daya Manusia Melalui Sekolah Menengah Kejuruan, Jakarta: Balai Pustaka, 1999.

[3] Menteri Pendidikan dan Kebudayaan RI, Peraturan Menteri Pendidikan dan Kebudayaan No.34 Tahun 2018 Tentang Standar Nasional Pendidikan SMK/MAK, 2018.

[4] Menteri Pendidikan dan Kebudayaan RI, Permendikbud No. 57 Tahun 2012 Tentang Ujian Kompetensi Guru, 2012.

[5] A. Mulyani, "Pengaruh Kinerja Kepala Sekolah dan Kinerja Guru Terhadap Pembelajaran SMK," Jurnal Administrasi Pendidikan, 2012.

[6] Kementerian Pendidikan dan Kebudayaan, "Neraca Pendidikan Daerah," 2019. [Online]. Available: https://npd.kemdikbud.go.id. [Accessed 20 Oktober 2020].

[7] S. Arikunto, Dasar-dasar Evaluasi Pendidikan Edisi 2, Jakarta: Bumi Aksara, 2012.

[8] M. Nasution and N. Darmayanti, "Pengaruh Latar Belakang Pendidikan dan Masa Kerja terhadap Kinerja Guru Raudhatul Athfal," Analitika, 2011.

[9] E. Nawipa, "Hubungan Pemberian Tunjangan Sertifikasi Guru dengan Motivasi dan Disiplin Kerja SMP di Oksibil Kab. Pegunungan 
Bintang," Jurnal Ilmu Pendidikan Indonesia, 2018.

[10] H. Murwati, "Pengaruh Sertifikasi Profesi Guru Terhadap Motivasi Kerja dan Kinerja Guru di SMK Negeri se-Surakarta," FKIP UNS, Semarang, 2012.

[11] D. E. Meliana, A. Hasyim and Y. Nurmalisa, "Pengaruh Sertifikasi Guru Terhadap Kompetensi Pedagogik dalam Mengajar di SMAN 1 Bangunrejo," Jurnal Kultur Demokrasi, 2018.

[12] A. Arfandi, Purnamawati and Nurfaedah, "The develoopment of a Thurstone scale for identifying teacher ability in using information and communication technology," Journal of Physics: Conference Series, 2020.

[13] Muslimin, "Program Penilaian Kinerja Guru dan Uji Kompetensi Guru dalam Meningkatkan Prestasi Kerja Guru," Indonesian Journal of Education Management \& Administration Review, 2020.

[14] F. Anggranei, "Realitas Kompetensi Guru Pasca Sertifikasi," Scientific Journal of Reflection, 2020.

[15] H. Harish, "Peningkatan Kinerja Guru Tidak Tetap (GTT) di SMP Negeri Lambandia Sulawesi Tenggara Melalui Masa Kerja, Kompensasi, Kompetensi, dan Kepuasan Kerja," Jurnal Ekonomi dan Bisnis, 2014.

[16] F. Ristianey, E. Harapan and D. Destinar, "Pengaruh Sertifikasi Guru dan Motivasi Kerja Terhadap Kinerja Guru," Jurnal Manajemen Kepemimpinan dan Supervisi Pendidikan, 2020.

[17] Mutakin and T. Zaenal, "Pengaruh Kompetensi, Kompensasi, dan Latar Belakang Terhadap Kinerja Guru," Jurnal Ilmiah Pendidikan MIPA, 2015.

[18] T. Ridwan and K. Sopandi, "Pengaruh Kepemimpinan Kepala Sekolah, Kompetensi Guru, dan Kompensasi Guru Terhadap
Kinerja Guru di SMP Pertiwi," Jurnal TEDC, 2019.

[19] I. Ismuha, K. Khairudin and A. Djalani, "Kompetensi Manajerial Kepala Sekolah Dalam Meningkatkan Kinerja Guru pada SDN Lamklat Kecamatan Darussalam Kabupaten Aceh Besar," Jurnal Administrasi Pendidikan Program Pascasarjana Unsyiah, 2016. 